\title{
Biological functions of macrophage-derived Wnt5a, and its roles in human diseases
}

\author{
Yue Shao ${ }^{1}$, Qianqian Zheng ${ }^{1}$, Wei Wang ${ }^{1}$, Na Xin ${ }^{1}$, Xiaowen Song ${ }^{1}$ and Chenghai \\ Zhao $^{1}$ \\ ${ }^{1}$ Department of Pathophysiology, College of Basic Medical Science, China Medical University, Shenyang, China \\ Correspondence to: Chenghai Zhao, email: zhaochenghail@sina.com \\ Keywords: Wnt5a, $\beta$-catenin, macrophage, angiogenesis, lymphangiogenesis \\ Received: December 08, $2015 \quad$ Accepted: August 27, $2016 \quad$ Published: September 06, 2016
}

\begin{abstract}
Wnt5a is implicated in development and tissue homeostasis by activating $\beta$-catenin-independent pathway. Excessive production of $\mathrm{Wnt5a}$ is related to some human diseases. Macrophage recruitment is a character of inflammation and cancer, therefore macrophage-derived Wnt5a is supposed to be a player in these conditions. Actually, macrophage-derived Wnt5a maintains macrophage immune function, stimulates pro-inflammatory cytokine release, and induces angiogenesis and lymphangiogenesis. Furthermore, macrophage-derived Wnt5a is involved in insulin resistance, atherosclerosis and cancer. These findings indicate that macrophagederived Wnt5a may be a target in the treatment of these diseases. Notably, unlike macrophages, the exact role of macrophage-derived Wnt5a in bacterial infection remains largely unknown.
\end{abstract}

\section{INTRODUCTION}

Human Wnt family include 19 members of highly conserved secreted proteins, which are critical to embryo development and adult tissue homeostasis [1]. Some Wnt proteins, such as Wnt1 and Wnt3a, activate canonical Wnt pathway. They bind to their membrane receptor Frizzleds (Fzds) and co-receptor lipoprotein receptor-related protein $5 / 6$ (LRP5/6), leading to $\beta$-catenin accumulation in the cytoplasm and translocation into the nucleus [2]. However, other proteins, such as Wnt5a and Wnt11, do not trigger Wnt/ $\beta$-catenin pathway. Generally, pathways stimulated by these proteins are called non-canonical Wnt pathways.

Macrophages are crucial for homeostasis, inflammation and immunity. As professional phagocytic cells, macrophages engulf and degrade cellular debris, dead/damaged cells, foreign substances and microbes. Moreover, macrophages initiate immune response to invading microbes and tissue regeneration upon injury. Macrophages can be found in all organs and take various forms, such as microglia, Kupffer cells, alveolar macrophages, Langerhans cells, histiocytes and others. For a long time, it has been believed that tissue-resident macrophages come from bone marrow derived monocytes (BMDM). However, recently accumulating evidence reveals that most of these tissue-resident macrophages arise from embryonic precursors which reside in these tissues prior to birth [3].

\section{WNT5A SIGNALING}

Non-canonical Wnt5a pathways (Figure 1) are usually initiated by the binding of Wnt5a to its receptor Fzds, including Fzd1-5[4-7], and Fzd7 [8, 9]. The intracellular pathways are mediated by some molecules, such as $\mathrm{Ca}^{2+}$, CaMKII, PKC and JNK [7, 10]. Ror1/2 are receptor tyrosine kinases, possessing an extracellular cysteine-rich domain (CRD) similar to the Wnt-binding sites of Fzds [11]. Wnt5a-Ror2 activates JNK signaling $[12,13]$ and TGF- $\beta$ signaling [14], whereas has no effect on intracellar $\mathrm{Ca}^{2+}$ level [6]. Fzds and Ror1/2 can form receptor complexes, which transduce Wnt5a signaling to activate Rho GTPase [8]. Receptor tyrosine kinase Ryk is another Wnt5a receptor [15], involved in the activation of TGF- $\beta$-SMAD signaling [16] and AKT signaling [9]. Fzds [5], Ror1/2 [17] and Ryk [18] all mediate Wnt5a-planar cell polarity (PCP) signaling, and both Ror2 [17] and Ryk [18] can form complex with Vangl2, a key component in PCP.

Wnt5a signaling may act on canonical Wnt $/ \beta$ catenin pathway. To a large extent, the action depends on the receptor type and the cellular context. Wnt5a inhibited 
Wnt3a-dependent $\beta$-catenin accumulation in HelaS3, MKN-1, CHO, and L cells [4]. In these cells, Wnt5a interfered with Wnt3a-induced LRP6 phosphorylation, and competed with Wnt3a for Fzd2 binding [4]. Wnt5aFzd 2 also suppressed $\beta$-catenin expression and activity in hepatocyte [19]. However, in HEK 293 cells, Wnt5aRor2 reduced $\beta$-catenin-dependent gene expression, but did not affect Wnt3a-induced $\beta$-catenin stabilization [6]. Moreover, Wnt5a inhibited $\beta$-catenin target gene expression in colon cancer cells via PKC-induced Ror $\alpha$ phosphorylation [20]. Intriguingly, Wnt5a could also activate $\mathrm{Wnt} / \beta$-catenin pathway, which depended on receptor Fzd4 [6].

\section{WNT5A EXPRESSION IN MACROPHAGES}

Basal Wnt5a expression was observed in peripheral blood mononuclear cell (PBMC) [21], PBMC-derived macrophage $[22,23]$, bone marrow-derived macrophage (BMDM) [24], alveolar macrophage [22], peritoneal macrophage, microglia [25] and macrophage cell line Raw264.7 [24]. Moreover, Wnt5a receptor Fzd5 expression was also found in macrophages [22-24], suggesting that Wnt5a can affect macrophages in an autocrinal manner. Fzd5 expression in macrophages also indicates that Wnt5a from other cells, such as tumor cells, can exert effects on macrophages in a paracrinal manner. Wnt5a expression in macrophages could be upregulated in response to bacterial stimulation, including LPS [22, $23,26,27]$. This process depended on Toll-like receptors (TLRs) and NF- $\kappa \mathrm{B}$ signaling $[22,26]$. IFN- $\gamma$ synergized with LPS in Wnt5a induction, which could be blocked by anti-inflammatory factor IL-10 [23, 26]. Intriguingly, in murine BMDM and murine microglia there was no upregulation of Wnt5a but Wnt6 [25, 28].

Under the sterile inflammatory conditions, proinflammatory cytokines can induce macrophages to secrete Wnt5a. Anti-TNF- $\alpha$ antibody blocked TNF$\alpha$-induced Wnt5a expression, whereas had no effect on mycobacteria- or LPS-induced Wnt5a production, suggesting TNF- $\alpha$-dependent Wnt5a induction is not related to LPS-TLR-NF- $\kappa$ B signaling [22]. IL-1 $\beta$, IL-6 and CCL2 could also stimulate Wnt5a expression in macrophages [23]. Actually, pro-inflammatory cytokines can induce Wnt5a expression in various cell types. For instance, TNF- $\alpha$ upregulated Wnt5a expression in bone marrow stromal cells (BMSCs) [29], mesenchymal stem cells (MSCs) [30], adipocytes [31], and human dental pulp cells (HDPCs) [32].

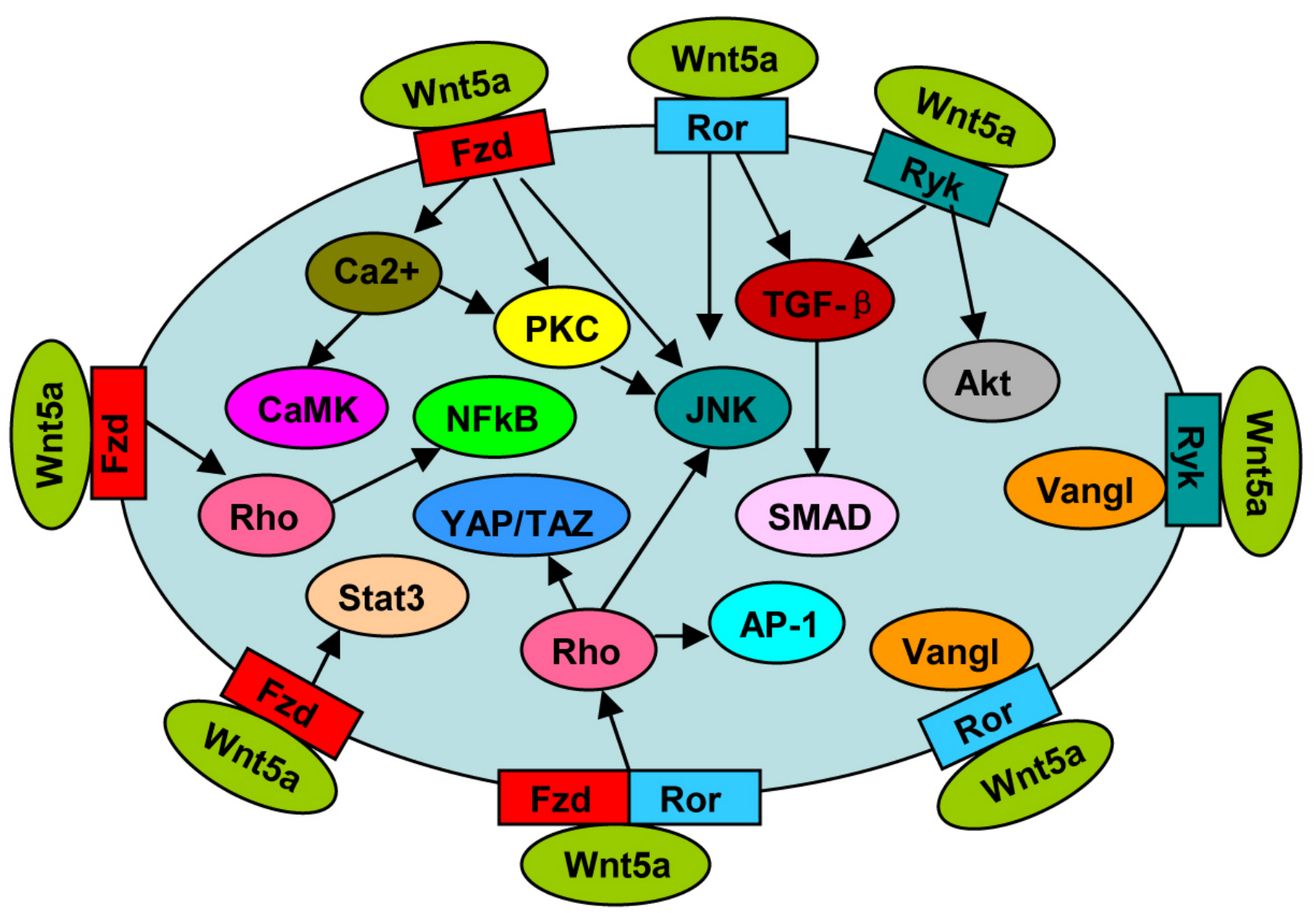

Figure 1: Wnt5a signal pathway. 
Non-inflammatory factors can also stimulate macrophages to overproduce Wnt5a. Oxidized Low density lipoprotein (Ox-LDL), but not native-LDL, induced Wnt5a expression in human macrophages, supporting the notion that macrophage-derived Wnt5a plays a positive role in atherosclerosis [33]. In coculture systems, breast cancer cells and basal cell carcinoma (BCC) cells provoked macrophages to produce Wnt5a [34-36]. In addition, Wnt5a expression was upregulated in hypoxia condition, suggesting that Wnt5a may be involved in the hypoxia-induced macrophage activation [37].

Importantly, macrophage-derived Wnt5a are not only secreted as soluble proteins, it is also delivered to the recipient cells through macrophage-derived exosomes and microvesicles, suggesting that macrophage-derived Wnt5a could have wide range effects [36].

\section{BIOLOGICAL FUNCTIONS OF MACRO- PHAGE-DERIVED WNT5A}

\section{Maintenance of macrophage immune function}

Monocytes can differentiate into macrophages or dendrite cells (DCs) dependent on the stimulator. Under the stimulation of monocyte-colony stimulator factor (GM-CSF), less bone marrow-derived monocytes from Wnt5a monocyte conditional knockout mice differentiated into $\mathrm{F} 4 / 80^{+}$and $\mathrm{CD} 1 \mathrm{~b}^{+}$macrophages, compared with those from control mice, demonstrating that Wnt5a is involved in macrophage differentiation[38]. In addition, Wnt5a-negative BMDMs displayed decreased survival, which was related to the reduced expression of antiapoptotic $\mathrm{Bcl} 2$ and $\mathrm{Bcl}-\mathrm{xl}$, and the increased expression of pro-apoptotic Bax [24]. Interestingly, $\beta$-catenin was also involved in macrophage proliferation and survival [39]. It is unknown whether interactions exist between the two Wnt pathways in macrophages.

Wnt5a inhibition reduced IFN- $\beta$ and IFN- $\gamma$ production by macrophages, and the underlying mechanism was related to the decreased I $\mathrm{B}$ kinase $\beta$ (IKK2) activity, which further resulted in suppressed I B degradation, and p65 nuclear translocation [24]. As p65 can bind to CD14 enhancer/promoter, Wnt5a pathway blocking also inhibited the expression of CD14 [24], a key component in TLR-dependent immune responses upon microbial infection. Wnt5a suppression also impaired macrophage phagocytosis, accompanied by a decrease in TNF- $\alpha$ and IL- 6 production, and an increase in IL-10 secretion [40]. These findings suggest that Wnt5a may be crucial to the maintenance of macrophage immune function.

\section{Induction of pro-inflammatory mediators}

It has been accepted that Wnt5a is a proinflammatory factor, based on the finding that Wnt5a induced pro-inflammatory cytokines in a variety of cell types, such as macrophages [23, 37], endothelial cells (ECs) [41], HDPCs [32], BMSCs [29], and synovial fibroblasts [42]. These cytokines include IL-6, IL-1 $\alpha$ and IL-1 $\beta$, which are extensively involved in human inflammatory diseases. Wnt5a also induced chemokines, such as CCL2 and IL-8 [23, 29, 32, 37, 41, 42], indicating that Wnt5a has a potential to recruit macrophages and neutrophils, which amplify inflammatory responses. Several signalings were identified to mediate the induction process, including $\mathrm{Ca}^{2+} / \mathrm{CaMKII}$ [23], $\mathrm{Ca}^{2+} / \mathrm{PKC}$ [41], NFкB [29, 32, 41], and MAPK [29, 32].

Loss and gain of function mice provided evidence that macrophage-derived Wnt5a attributed to adipose tissue inflammation. Expression of TNF-a and IL-6 was remarkably decreased in obese myeloid Wnt5a knockout mice, whereas increased in obese myeloidrestricted Wnt5a overexpression mice [43]. IL-6 treatment restored insulin resistance in obese Wnt5a-deficient mice, suggesting this inflammatory cytokines in adipose tissue promote obesity-induced metabolic dysfunction [43]. Accordingly, in vitro studies showed that rWnt5a stimulated macrophages and adipocytes to express IL-6 via intracellular JNK signaling, which could be blocked by Wnt5a antagonist secreted Frizzled-related protein 5 (SFRP5) [44].

Several studies demonstrated that Wnt5a may exert complicated effects on macrophages. Wnt5a and LPS induced pro-inflammatory cyclooxygenase 2 (COX-2) in microglia, respectively, however, Wnt5a inhibited LPSinduced COX-2 upregulation [45]. Moreover, Wnt5a suppressed LPS-induced activation of NF- $\kappa \mathrm{B}$, a key factor in pro-inflammatory cell signaling [46]. These results suggest that Wnt5a may play anti-inflammatory roles in some inflammatory conditions.

\section{Dual roles in angiogenesis}

Early evidence for the involvement of Wnt5a signaling in angiogenesis came from the study on Fzd5 knockout mice, which died in utero due to defective angiogenesis in yolk sac [47]. Wnt5a and its recptor Fzd5 co-expressed in the developing yolk sac, therefore, Fzd5 deficiency-induced angiogenesis defect may be attributed to impaired Wnt5a signaling. Study on endothelial Wntless (Wls) knockout mice further supported the positive role of Wnt5a in angiogenesis. Wls is a transporter for Wnt proteins. These mice exhibited impaired vascularization, accompanied by decreased EC survival and proliferation, and importantly, the angiogenesis defect could be rescued by introduction of Wnt5a [48]. Furthermore, treatment 
A

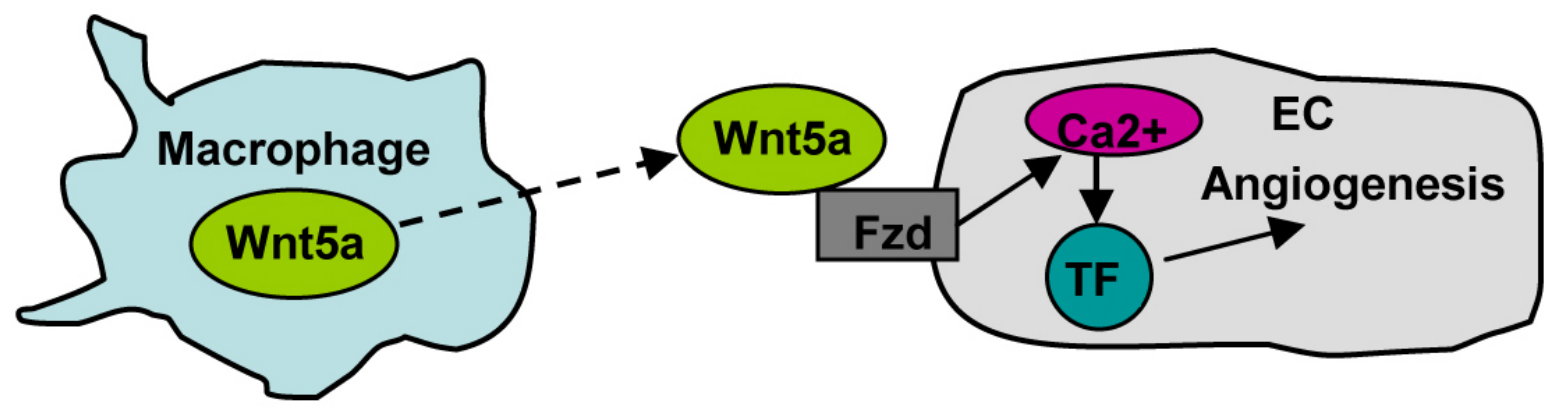

B
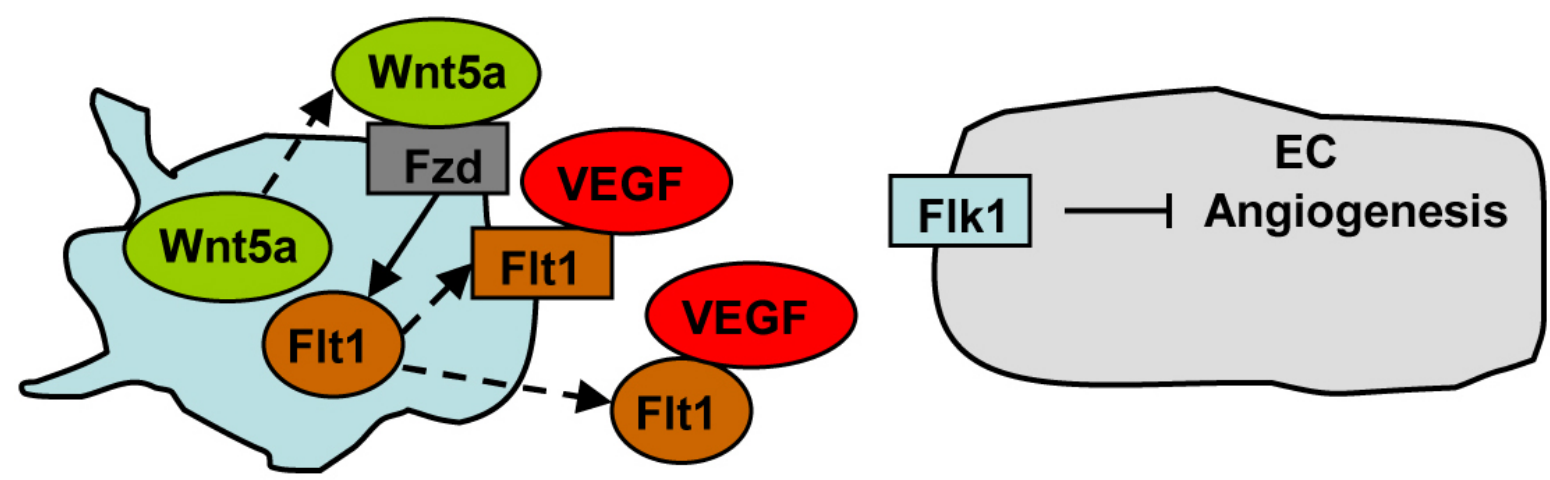

C
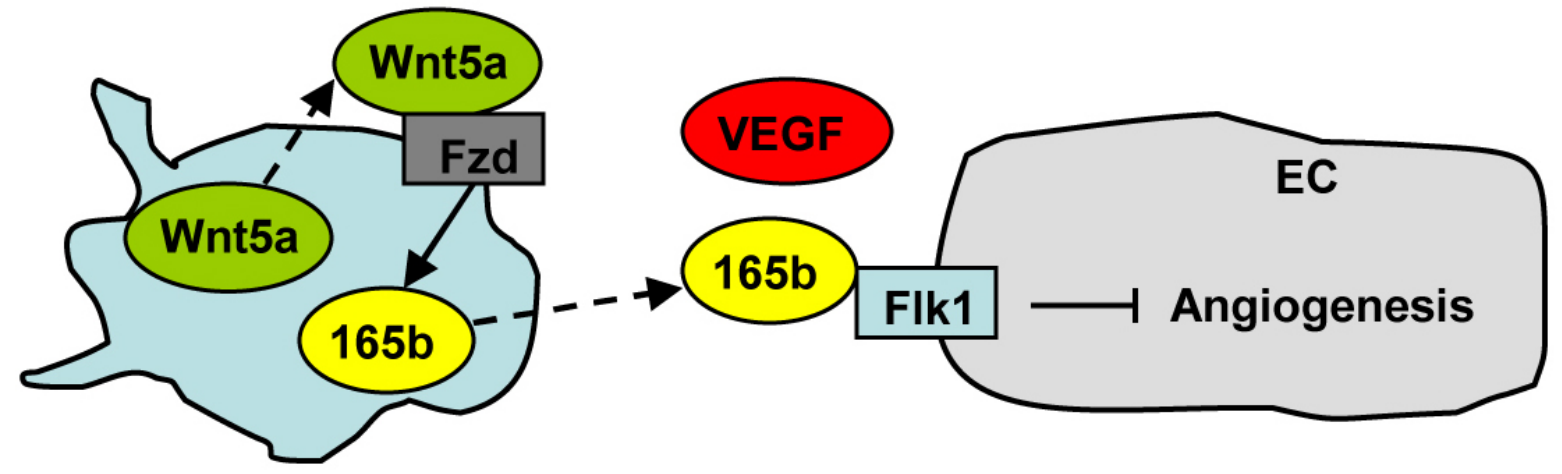

D

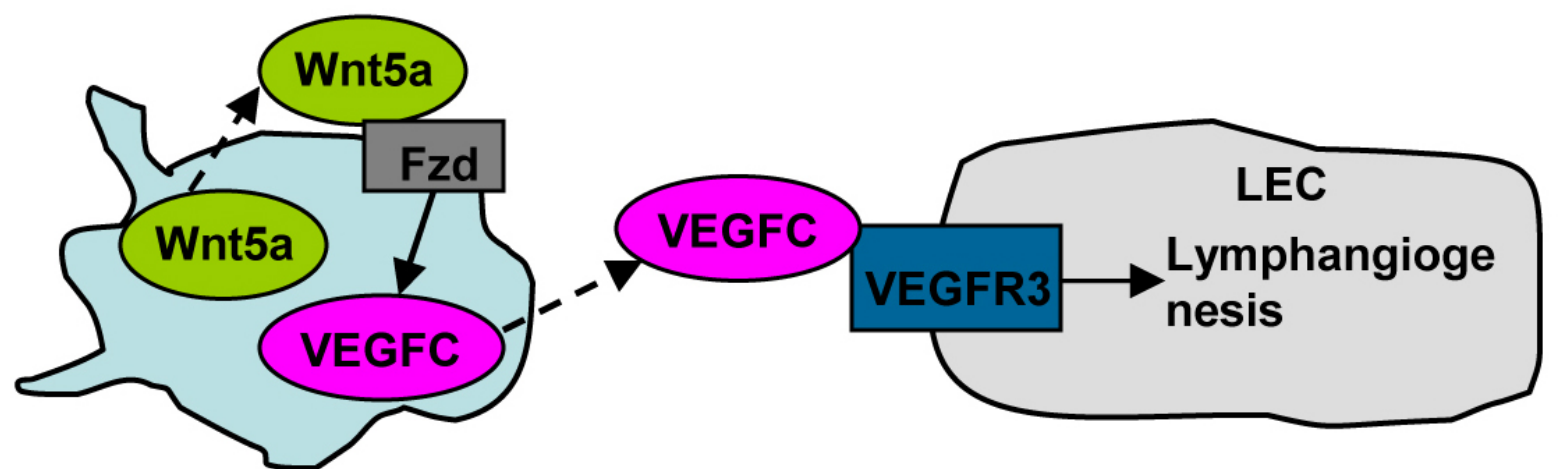

Figure 2: The role of macrophage-derived Wnt5a in angiogenesis and lymphangiogenesis. A. Macrophage-derived Wnt5a induces angiogenesis by upregulating TF expression in ECs. B. Macrophage-derived Wnt5a inhibits angiogenesis by producing VEGF inhibitory receptor Flt1. C. Macrophage-derived Wnt5a inhibits angiogenesis by producing anti-angiogenic isoform of VEGF-A, VEGFA165b. D. Macrophage-derived Wnt5a stimulates lymphangiogenesis by producing VEGF-C. 
of mice with the non-canonical Wnt inhibitor TNP470 induced similar angiogenesis defect and EC proliferation inhibition to Wls knockout mice [48].

In vitro studies directly indicated that Wnt5a overexpression stimulated EC proliferation and survival. Some Wnt5a-target genes were identified, such as matrix metalloproteinase-1 (MMP-1) and Tie-2 [49]. On the contrary, Wnt5a downregulation or blocking inhibited EC proliferation and migration $[49,50]$. In addition, tumor cell-derived Wnt5a was also involved in angiogenesis. For instance, melanoma cells released pro-angiogenic factor IL-6, vascular endothelial growth factor (VEGF) and MMP2, in a Wnt5a-dependent manner, and coculture of Wnt5a-silenced melanoma cells with ECs showed decreased EC branching, compared with control melanoma cells [51].

Angiogenesis is a character of both tumor development and tissue repair. Substantial evidence demonstrated that infiltrating macrophages attributed to tumor angiogenesis [52-54]. Macrophage recruitment in tumor microenvironment usually resulted from the expression of CCL2 by tumor cells [52-54]. Macrophages also promoted angiogenesis in some other pathological and physiological conditions. CD11b knockout mice exhibited impaired angiogenesis after partial hepatectomy [55]. Macrophages induced angiogenesis during liver fibrosis in an animal model treated with tetrachloride and bile duct ligation [56]. Moreover, PGC-1 $\alpha$-induced macrophage recruitment stimulated skeletal muscle angiogenesis [57]. As both Wnt5a and macrophages are implicated in angiogenesis, it is reasonable to speculate that macrophage-derived Wnt5a may stimulate angiogenesis. Indeed, it was observed that monocyte-secreted Wnt5a induced angiogenesis by upregulating tissue factor (TF) expression in ECs; this process depended on Fzd5, and involved $\mathrm{Ca}^{2+}$ signaling and $\mathrm{NF} \kappa \mathrm{B}$ pathway [58] (Figure 2A).

However, Wnt5a exhibits an inhibitory effect on angiogenesis in some other conditions. One mechanism is related to VEGF inhibitory receptor Flt1 (fms-like

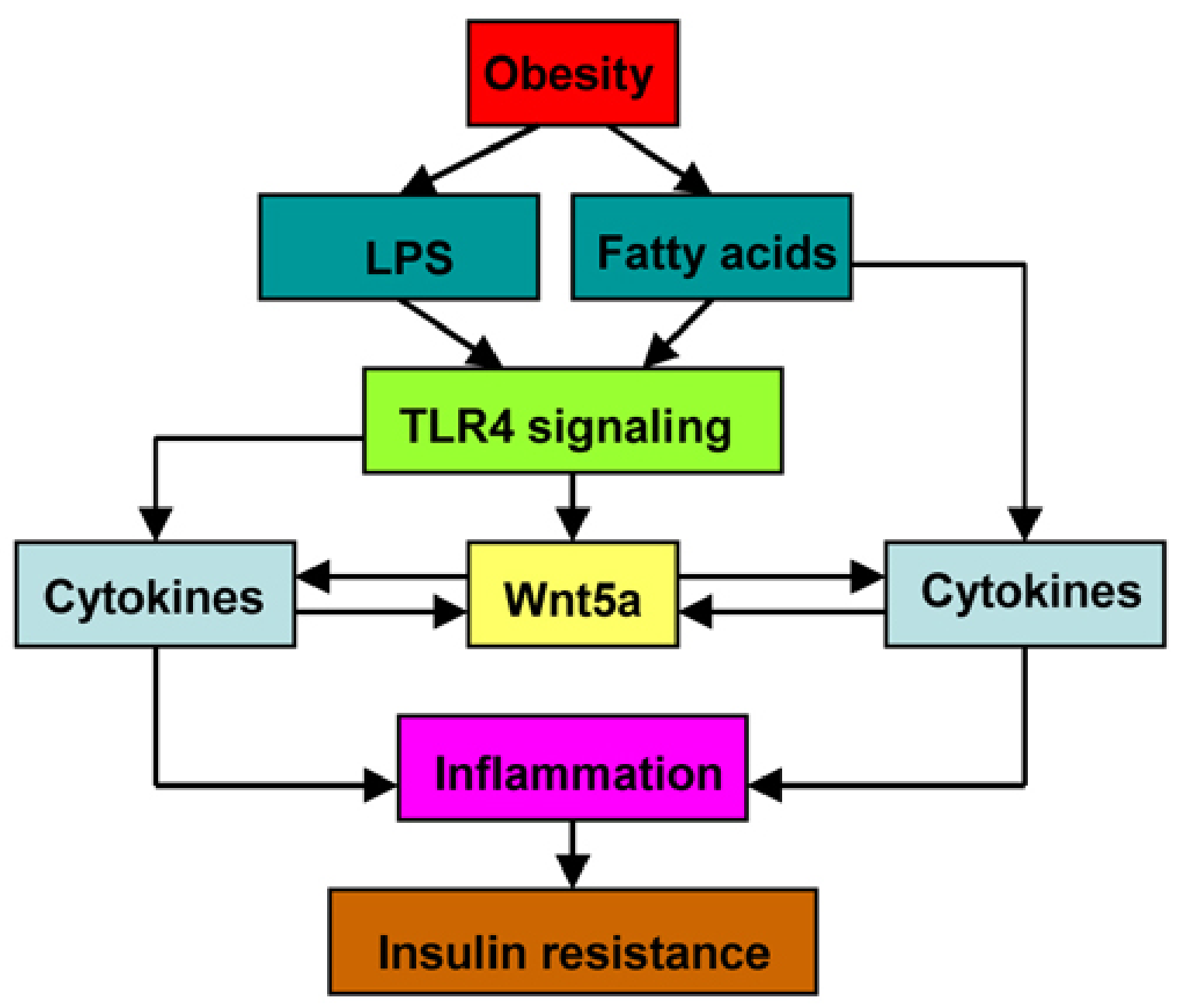

Figure 3 The involvement of macrophage-derived Wnt5a in adipose inflammation and insulin resistance. Wnt5a acts as an "amplifier" in adipose tissue inflammation. 
tyrosine kinase-1), also called VEGFR1, which has a higher affinity with VEGF than Flk1 (VEGFR2), but has limited signaling capacity (Figure 2B). Macrophagederived Wnt5a induced Flt1 expression, which suppressed angiogenesis in postnatal retina and during wound repair [59, 60]. It was also shown that macrophage Raw264.7 expressed membrane and soluble Flt1 under the stimulation of exogenous Wnt5a [59]. Furthermore, macrophage-derived Wnt5a inhibited ischemia-induced angiogenesis by upregulating VEGF-A165b, an antiangiogenic isoform of VEGF-A [61] (Figure 2C).

\section{Induction of lymphangiogenesis}

Lymphangiogenesis is a character of both inflammation and cancer. It has been well accepted that macrophages are crucial for lymphangiogenesis in a various pathological or physiological conditions. VEGF-C/D from macrophages are the major contributors to lymphangiogenesis, especially under the action of inflammatory stimuli, such as LPS, IL- $1 \beta$ and TNF- $\alpha$ [62-65]. VEGF-C/D combined with VEGFR3 in lymphatic endothelial cell, initiating the signaling for lymphangiogenesis [66-68]. Overexpression of VEGF$\mathrm{C} / \mathrm{D}$ in tumor-associated macrophages (TAMs) attributed to lymphangiogenesis in tumors, which may promote tumor metastasis [65].

Evidence for the involvement of Wnt5a in lymphangiogenesis was provided by a study using Wnt5a knockout mice, which showed a reduction in the number of dermal lymphatic capillaries [69]. This study revealed the expression of Wnt5a and its receptor ROR1/2 and RYK in lymphatic endothelial cells (LECs), suggesting that LEC-derived Wnt5a may promote lymphangiogenesis in an autocrinal manner, just like ECderived Wnt5a in promoting angiogenesis. It is unknown whether LEC-derived Wnt5a induces lymphangiogenesis via VEGF-C. The role of macrophage-derived Wnt5a in lymphangiogenesis was investigated recently using Wnt5a monocyte conditional knockout mice, which displayed reduced lymphangiogenesis in the corneas, accompanied by a reduction in VEGF-C expression [38] (Figure 2D).

\section{ROLES OF MACROPHAGE-DERIVED WNT5A IN HUMAN DISEASES}

\section{Insulin resistance and diabetes}

Animal studies have demonstrated that Wnt5a is an important player in insulin resistance and diabetes. Early evidence came from a study on SFRP5 knockout

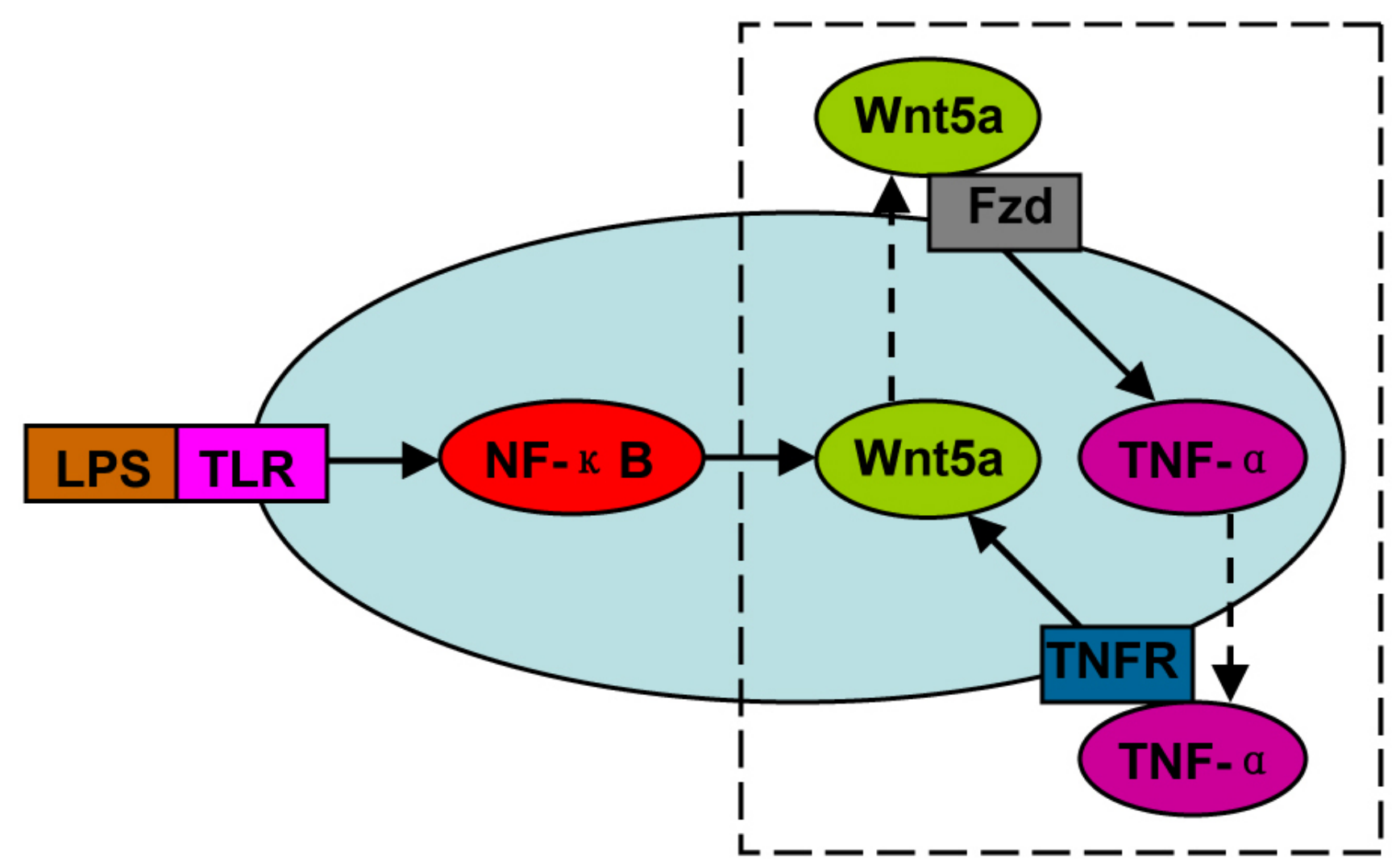

Figure 4 The positive feedback loop between Wnt5a and inflammatory cytokines (e.g. TNF- $\alpha$ ). This loop can be triggered by LPS-TLR-NF- $\kappa$ B signaling, and amplify the inflammatory responses. 
mice. SFRP5 is a Wnt5a antagonist, therefore, SFRP5 expression loss exaggerated the pro-inflammatory effects of Wnt5a, which was shown to be induced by obesity [44]. Administration of exogenous SFRP5 or ablation of JNK ameliorated insulin resistance, accompanied by a reduction in adipose tissue inflammation [44]. Similar results were observed in whole body Wnt5a knockout mice, which showed that Wnt5a ablation attenuated highfat/high-sucrose (HFHS)-induced insulin resistance, and these mice displayed decreased expression of TNF- $\alpha$, CCL2, and IL-6 in adipose tissue [43].

Study on myeloid Wnt5a knockout mice provided direct evidence that macrophage-derived Wnt5a mediated obesity-induced glucose metabolic dysfunction [43]. As expected, due to the partial ablation of Wnt5a expression, these mice displayed a milder phenotype than whole body Wnt5a knockout mice under HFHS [43]. Myeloidrestricted Wnt5a overexpression mice further confirmed the positive role of macrophage-derived $\mathrm{Wnt} 5 \mathrm{a}$ in insulin resistance and diabetes. They exhibited enhanced pro-inflammatory cytokine production and glucose intolerance [43]. The mechanism behind the obesityinduced Wnt5a upregulation remains largely unknown. It may be attributed to metabolic entoxemia [70, 71] and increased level of fatty-acids $[72,73]$ induced by highfat diet (Figure 3). As described previously, both LPS and pro-inflammatory cytokines are potent Wnt5a stimulators. Notably, LPS or TNF- $\alpha$ treatment also upregulated Wnt5a expression in adipocytes [31], indicating that adipocytederived Wnt5a is also implicated in adipose tissue inflammation and insulin resistance.

\section{Atherosclerosis}

As an inflammatory disease, atherosclerosis is characterized by the accumulation of macrophages in the intima. Immunohistochemical analysis showed Wnt5a expression in human and murine atherosclerotic lesions, especially in the areas of macrophage infiltration, and was coincident with TLR-4 expression [74]. Wnt5a induction may be attributed to ox-LDL, which was shown to stimulate Wnt5a expression in human macrophages in vitro [33]. Wnt5a level was significantly higher in serum from atherosclerotic patients compared with healthy persons, and was correlated with the severity of atherosclerotic lesions [33, 74]. Furthermore, Wnt5a was involved in vascular calcification, a hallmark of advanced atherosclerosis [75]. Importantly, anti-Wnt5a treatment inhibited atherosclerotic development in apolipoprotein E-deficient (ApoE-/-) mice fed a high-fat diet, accompanied by reduced expression of inflammatory cytokines [76].

\section{Cancer}

Wnt5a displays multifunctional in human malignancies. Wnt5a loss was found in leukemias [77, 78], ovarian cancers [79], and thyroid carcinomas [80]. In these malignancies, Wnt5a acted as a tumor suppressor mainly via antagonizing carcinogenetic $\mathrm{Wnt} / \beta$-catenin pathway. However, in other human tumors, such as melanoma and pancreatic cancer, Wnt5a increased tumor cell invasion and migration through actin reorganization, cell adhesion and epithelial to mesenchymal transition (EMT) [81-83]. These studies indicate that Wnt5a may inhibit $\beta$-cateninrelated carcinogenesis, but promote tumor progression via $\beta$-catenin-independent mechanisms. The exact role of Wnt5a in human cancers depends on the tumor context.

As macrophages are a source of Wnt5a, it is interesting to explore the role of TAM-derived Wnt5a in human malignancies. Wnt5a expression was observed in TAMs in human breast cancers [34] and colon cancers [84]. Coculture experiments showed that tumors cells induced Wnt5a expression in macrophages [34-36]. Some particles from breast cancer cells were responsible for the upregulation of Wnt5a in macrophages [36]. Conversely, macrophage-derived Wnt5a promoted breast cancer cell invasiveness [34] and gastric cancer cell migration [27]. The reciprocal interaction between tumor cells and macrophages do not always promote tumor progression. It was observed that macrophage-derived Wnt5a induced $\mathrm{BCC}$ cell differentiation and regression [35].

\section{CONCLUSIONS}

Consistent with the characterized infiltration of macrophages in inflammation and cancer, macrophagederived Wnt5a has been proved to be involved in human inflammatory diseases and cancers, mainly by inducing pro-inflammatory cytokine release, angiogenesis and lymphangiogenesis. A positive feedback loop exists between Wnt5a and inflammatory cytokines, supported by the finding that inflammatory cytokines are also potent inducers of Wnt5a (Figure 4). This loop may be triggered by LPS-TLR-NF- $\kappa \mathrm{B}$ signaling, and aggravate the inflammatory responses. These findings clearly demonstrate that macrophage-derived Wnt5a should be considered as a target in the treatment of these diseases.

LPS induced Wnt5a production by macrophages via TLR-NF- $\kappa \mathrm{B}$ signaling, and Wnt5a signaling inhibition reduced IFN- $\beta$ and IFN- $\gamma$ production and CD14 expression by macrophages, suggesting that Wnt5a may be a component in macrophage innate immunity [24]. Inconsistently, although Wnt5a-Fzd5 signaling enhanced macrophage phagocytosis, it was not accompanied by an increase in bacteria killing, and on the contrary, Wnt5a inhibitor IWP-2 reduced macrophage phagocytosis, but increased bacterial killing [40]. These finding indicate that 
more investigations are needed to explore the exact role of macrophage-derived Wnt5a in infection and sepsis.

Tumor cell-derived Wnt5a has been demonstrated to play a dual role in human cancer initiation and progression. However, few studies have focused on the exact role of TAM-derived Wnt5a. Does TAM-derived Wnt5a promote cancer cell migration by inducing angiogenesis and lymphangiogenesis? Does TAM-derive Wnt5a trigger local inflammation in the tumor microenvironment? Actually, inflammation has been considered as a hallmark of cancer. And how does TAM-derive Wnt5a regulate TAM immune function? A reasonable speculation is that Wnt5a may in part mediate the action of TAMs on cancers, and more studies are needed to answer these questions.

\section{ACKNOWLEDGMENTS}

This work was supported by National Natural Science Foundation of China (No. 81370517) and Natural Science Foundation of Liaoning Province (No. 2014021036).

\section{CONFLICTS OF INTEREST}

There is no financial conflict of interest concerning this study.

\section{REFERENCES}

1. Logan CY, Nusse R. The Wnt signaling pathway in development and disease. Annu Rev Cell Dev Biol. 2004;20:781-810.

2. Song $X$, Xin N, Wang W, Zhao C. Wnt/ $\beta$-catenin, an oncogenic pathway targeted by $\mathrm{H}$. pylori in gastric carcinogenesis. Oncotarget. 2015;6:35579-35588. doi: 10.18632/oncotarget.5758.

3. Ginhoux F, Guilliams M. Tissue-Resident Macrophage Ontogeny and Homeostasis. Immunity. 2016;44:439-449.

4. Sato A, Yamamoto H, Sakane H, Koyama H, Kikuchi A. Wnt5a regulates distinct signalling pathways by binding to Frizzled2. EMBO J. 2010;29:41-54.

5. Fenstermaker AG, Prasad AA, Bechara A, Adolfs Y, Tissir F, Goffinet A, Zou Y, Pasterkamp RJ. Wnt/planar cell polarity signaling controls the anterior-posterior organization of monoaminergic axons in the brainstem. J Neurosci. 2010;30:16053-16064.

6. Mikels AJ, Nusse R. Purified Wnt5a protein activates or inhibits beta-catenin-TCF signaling depending on receptor context. PLoS Biol. 2006;4:e115.

7. Weeraratna AT, Jiang Y, Hostetter G, Rosenblatt K, Duray P, Bittner M, Trent JM. Wnt5a signaling directly affects cell motility and invasion of metastatic melanoma. Cancer Cell. 2002;1:279-288.

8. Nishita M, Itsukushima S, Nomachi A, Endo M, Wang Z,
Inaba D, Qiao S, Takada S, Kikuchi A, Minami Y. Ror2/ Frizzled complex mediates Wnt5a-induced AP-1 activation by regulating Dishevelled polymerization. Mol Cell Biol. 2010;30:3610-3619.

9. Anastas JN, Kulikauskas RM, Tamir T, Rizos H, Long GV, von Euw EM, Yang PT, Chen HW, Haydu L, Toroni RA, Lucero OM, Chien AJ, Moon RT. WNT5A enhances resistance of melanoma cells to targeted BRAF inhibitors. J Clin Invest. 2014;124:2877-2890.

10. Liang H, Chen Q, Coles AH, Anderson SJ, Pihan G, Bradley A, Gerstein R, Jurecic R, Jones SN. Wnt5a inhibits $\mathrm{B}$ cell proliferation and functions as a tumor suppressor in hematopoietic tissue. Cancer Cell. 2003;4:349-360.

11. Oishi I, Suzuki H, Onishi N, Takada R, Kani S, Ohkawara B, Koshida I, Suzuki K, Yamada G, Schwabe GC, Mundlos S, Shibuya H, Takada S, Minami Y. The receptor tyrosine kinase Ror2 is involved in non-canonical Wnt5a/JNK signalling pathway. Genes Cells. 2003;8:645-654.

12. Maeda K, Kobayashi Y, Udagawa N, Uehara S, Ishihara A, Mizoguchi T, Kikuchi Y, Takada I, Kato S, Kani S, Nishita M, Marumo K, Martin TJ, Minami Y, Takahashi N. Wnt5a-Ror2 signaling between osteoblast-lineage cells and osteoclast precursors enhances osteoclastogenesis. Nat Med. 2012;18:405-412.

13. Nomachi A, Nishita M, Inaba D, Enomoto M, Hamasaki M, Minami Y. Receptor tyrosine kinase Ror2 mediates Wnt5a-induced polarized cell migration by activating c-Jun $\mathrm{N}$-terminal kinase via actin-binding protein filamin A. J Biol Chem. 2008;283:27973-27981.

14. Miyoshi H, Ajima R, Luo CT, Yamaguchi TP, Stappenbeck TS. Wnt5a potentiates TGF- $\beta$ signaling to promote colonic crypt regeneration after tissue injury. Science. 2012;338:108-113.

15. Yoshikawa S, McKinnon RD, Kokel M, Thomas JB. Wnt-mediated axon guidance via the Drosophila Derailed receptor. Nature. 2003;422:583-588.

16. Borcherding N, Kusner D, Kolb R, Xie Q, Li W, Yuan F, Velez G, Askeland R, Weigel RJ, Zhang W. Paracrine WNT5A Signaling Inhibits Expansion of Tumor-Initiating Cells. Cancer Res. 2015;75:1972-1982.

17. Gao B, Song H, Bishop K, Elliot G, Garrett L, English MA, Andre P, Robinson J, Sood R, Minami Y, Economides AN, Yang Y. Wnt signaling gradients establish planar cell polarity by inducing Vang12 phosphorylation through Ror2. Dev Cell. 2011;20:163-176.

18. Andre P, Wang Q, Wang N, Gao B, Schilit A, Halford MM, Stacker SA, Zhang X, Yang Y. The Wnt coreceptor Ryk regulates Wnt/planar cell polarity by modulating the degradation of the core planar cell polarity component Vang12. J Biol Chem. 2012;287:44518-44525.

19. Yang J, Cusimano A, Monga JK, Preziosi ME, Pullara F, Calero G, Lang R, Yamaguchi TP, Nejak-Bowen KN, Monga SP. WNT5A inhibits hepatocyte proliferation and concludes $\beta$-catenin signaling in liver regeneration. Am J 
Pathol. 2015;185:2194-2205.

20. Lee JM, Kim IS, Kim H, Lee JS, Kim K, Yim HY, Jeong J, Kim JH, Kim JY, Lee H, Seo SB, Kim H, Rosenfeld MG, Kim KI, Baek SH. RORalpha attenuates Wnt/beta-catenin signaling by PKCalpha-dependent phosphorylation in colon cancer. Mol Cell. 2010;37:183-195.

21. Lehtonen A, Ahlfors $H$, Veckman V, Miettinen $M$, Lahesmaa R, Julkunen I. Gene expression profiling during differentiation of human monocytes to macrophages or dendritic cells. J Leukoc Biol. 2007;82:710-720.

22. Blumenthal A, Ehlers S, Lauber J, Buer J, Lange C, Goldmann T, Heine H, Brandt E, Reiling N. The Wingless homolog WNT5A and its receptor Frizzled-5 regulate inflammatory responses of human mononuclear cells induced by microbial stimulation. Blood. 2006;108:965973.

23. Pereira C, Schaer DJ, Bachli EB, Kurrer MO, Schoedon G. Wnt5A/CaMKII signaling contributes to the inflammatory response of macrophages and is a target for the antiinflammatory action of activated protein $\mathrm{C}$ and interleukin-10. Arterioscler Thromb Vasc Biol. 2008;28:504-510.

24. Naskar D, Maiti G, Chakraborty A, Roy A, Chattopadhyay D, Sen M. Wnt5a-Rac1-NF- $\mathrm{B}$ homeostatic circuitry sustains innate immune functions in macrophages. $\mathrm{J}$ Immunol. 2014;192:4386-4397.

25. Pukrop T, Dehghani F, Chuang HN, Lohaus R, Bayanga K, Heermann S, Regen T, Van Rossum D, Klemm F, Schulz M, Siam L, Hoffmann A, Trümper L, Stadelmann C, Bechmann I, Hanisch UK, Binder C. Microglia promote colonization of brain tissue by breast cancer cells in a Wntdependent way. Glia. 2010;58:1477-1489.

26. Nanbara H, Wara-aswapati N, Nagasawa T, Yoshida Y, Yashiro R, Bando Y, Kobayashi H, Khongcharoensuk J, Hormdee D, Pitiphat W, Boch JA, Izumi Y. Modulation of Wnt5a expression by periodontopathic bacteria. PLoS One. 2012;7:e34434.

27. Zhao C, Ma H, Bu X, Wang W, Zhang N. SFRP5 inhibits gastric epithelial cell migration induced by macrophagederived Wnt5a. Carcinogenesis. 2013;34:146-152.

28. Schaale K, Brandenburg J, Kispert A, Leitges M, Ehlers S, Reiling N. Wnt6 is expressed in granulomatous lesions of Mycobacterium tuberculosis-infected mice and is involved in macrophage differentiation and proliferation. J Immunol. 2013;191:5182-5195.

29. Rauner M, Stein N, Winzer M, Goettsch C, Zwerina J, Schett G, Distler JH, Albers J, Schulze J, Schinke T, Bornhäuser M, Platzbecker U, Hofbauer LC. WNT5A is induced by inflammatory mediators in bone marrow stromal cells and regulates cytokine and chemokine production. $\mathrm{J}$ Bone Miner Res. 2012;27:575-585.

30. Briolay A, Lencel P, Bessueille L, Caverzasio J, Buchet R, Magne D. Autocrine stimulation of osteoblast activity by Wnt5a in response to TNF- $\alpha$ in human mesenchymal stem cells. Biochem Biophys Res Commun. 2013;430:10721077.

31. Catalán V, Gómez-Ambrosi J, Rodríguez A, PérezHernández AI, Gurbindo J, Ramírez B, Méndez-Giménez L, Rotellar F, Valentí V, Moncada R, Martí P, Sola I, Silva C, Salvador J, Frühbeck G. Activation of noncanonical Wnt signaling through WNT5A in visceral adipose tissue of obese subjects is related to inflammation. J Clin Endocrinol Metab. 2014;99:E1407-1417.

32. Zhao Y, Wang CL, Li RM, Hui TQ, Su YY, Yuan Q, Zhou $\mathrm{XD}$, Ye L. Wnt5a promotes inflammatory responses via nuclear factor $\kappa \mathrm{B}(\mathrm{NF}-\kappa \mathrm{B})$ and mitogen-activated protein kinase (MAPK) pathways in human dental pulp cells. J Biol Chem. 2014;289:21028-21039.

33. Bhatt PM, Lewis CJ, House DL, Keller CM, Kohn LD, Silver MJ, McCall KD, Goetz DJ, Malgor R. Increased Wnt5a mRNA Expression in Advanced Atherosclerotic Lesions, and Oxidized LDL Treated Human MonocyteDerived Macrophages. Open Circ Vasc J. 2012;5:1-7.

34. Pukrop T, Klemm F, Hagemann T, Gradl D, Schulz M, Siemes S, Trümper L, Binder C. Wnt 5a signaling is critical for macrophage-induced invasion of breast cancer cell lines. Proc Natl Acad Sci U S A. 2006;103:5454-5459.

35. Nitzki F, Zibat A, König S, Wijgerde M, Rosenberger A, Brembeck FH, Carstens PO, Frommhold A, Uhmann A, Klingler S, Reifenberger J, Pukrop T, Aberger F, SchulzSchaeffer W, Hahn H. Tumor stroma-derived Wnt5a induces differentiation of basal cell carcinoma of Ptchmutant mice via CaMKII. Cancer Res. 2010;70:2739-2748.

36. Menck K, Klemm F, Gross JC, Pukrop T, Wenzel D, Binder C. Induction and transport of Wnt 5a during macrophageinduced malignant invasion is mediated by two types of extracellular vesicles. Oncotarget. 2013;4:2057-2066. doi: 10.18632/oncotarget.1336.

37. Kim J, Chang W, Jung Y, Song K, Lee I. Wnt5a activates THP-1 monocytic cells via a $\beta$-catenin-independent pathway involving JNK and NF- $\mathrm{KB}$ activation. Cytokine. 2012;60:242-248.

38. Sessa R, Yuen D, Wan S, Rosner M, Padmanaban P, Ge $\mathrm{S}$, Smith A, Fletcher R, Baudhuin-Kessel A, Yamaguchi TP, Lang RA, Chen L. Monocyte-derived Wnt5a regulates inflammatory lymphangiogenesis. Cell Res. 2016; 26:262265.

39. Otero K, Turnbull IR, Poliani PL, Vermi W, Cerutti E, Aoshi T, Tassi I, Takai T, Stanley SL, Miller M, Shaw AS, Colonna M. Macrophage colony-stimulating factor induces the proliferation and survival of macrophages via a pathway involving DAP12 and beta-catenin. Nat Immunol. 2009; 10:734-743.

40. Maiti G, Naskar D, Sen M. The Wingless homolog Wnt5a stimulates phagocytosis but not bacterial killing. Proc Natl Acad Sci U S A. 2012;109:16600-16605.

41. Kim J, Kim J, Kim DW, Ha Y, Ihm MH, Kim H, Song $\mathrm{K}$, Lee I. Wnt5a induces endothelial inflammation via beta- 
catenin-independent signaling. J Immunol. 2010;185:12741282.

42. Sen M, Lauterbach K, El-Gabalawy H, Firestein GS, Corr $\mathrm{M}$, Carson DA. Expression and function of wingless and frizzled homologs in rheumatoid arthritis. Proc Natl Acad Sci U S A. 2000;97:2791-2796.

43. Fuster JJ, Zuriaga MA, Ngo DT, Farb MG, Aprahamian T, Yamaguchi TP, Gokce N, Walsh K. Noncanonical Wnt signaling promotes obesity-induced adipose tissue inflammation and metabolic dysfunction independent of adipose tissue expansion. Diabetes. 2015 ;64:1235-1248.

44. Ouchi N, Higuchi A, Ohashi K, Oshima Y, Gokce N, Shibata R, Akasaki Y, Shimono A, Walsh K. Sfrp5 is an anti-inflammatory adipokine that modulates metabolic dysfunction in obesity. Science. 2010;329:454-457.

45. Halleskog C, Schulte G. WNT-3A and WNT-5A counteract lipopolysaccharide-induced pro-inflammatory changes in mouse primary microglia. J Neurochem. 2013;125:803-808.

46. Bergenfelz C, Medrek C, Ekström E, Jirström K, Janols $\mathrm{H}$, Wullt M, Bredberg A, Leandersson K. Wnt5a induces a tolerogenic phenotype of macrophages in sepsis and breast cancer patients. J Immunol. 2012;188:5448-5458.

47. Ishikawa T, Tamai Y, Zorn AM, Yoshida H, Seldin MF, Nishikawa S, Taketo MM. Mouse Wnt receptor gene Fzd5 is essential for yolk sac and placental angiogenesis. Development. 2001;128:25-33.

48. Korn C, Scholz B, Hu J, Srivastava K, Wojtarowicz J, Arnsperger T, Adams RH, Boutros M, Augustin HG, Augustin I. Endothelial cell-derived non-canonical Wnt ligands control vascular pruning in angiogenesis. Development. 2014;141:1757-1766.

49. Masckauchán TN, Agalliu D, Vorontchikhina M, Ahn A, Parmalee NL, Li CM, Khoo A, Tycko B, Brown AM, Kitajewski J. Wnt5a signaling induces proliferation and survival of endothelial cells in vitro and expression of MMP-1 and Tie-2. Mol Biol Cell. 2006;17:5163-5172.

50. Cheng CW, Yeh JC, Fan TP, Smith SK, Charnock-Jones DS. Wnt5a-mediated non-canonical Wnt signalling regulates human endothelial cell proliferation and migration. Biochem Biophys Res Commun. 2008;365:285290.

51. Ekström EJ, Bergenfelz C, von Bülow V, Serifler F, Carlemalm E, Jönsson G, Andersson T, Leandersson K. WNT5A induces release of exosomes containing proangiogenic and immunosuppressive factors from malignant melanoma cells. Mol Cancer. 2014;13:88.

52. Low-Marchelli JM, Ardi VC, Vizcarra EA, van Rooijen N, Quigley JP, Yang J. Twist1 induces CCL2 and recruits macrophages to promote angiogenesis. Cancer Res. 2013;73:662-671.

53. Kawada M, Seno H, Kanda K, Nakanishi Y, Akitake R, Komekado H, Kawada K, Sakai Y, Mizoguchi E, Chiba T. Chitinase 3-like 1 promotes macrophage recruitment and angiogenesis in colorectal cancer. Oncogene. 2012;31:3111-
3123.

54. Arendt LM, McCready J, Keller PJ, Baker DD, Naber SP, Seewaldt V, Kuperwasser C. Obesity promotes breast cancer by CCL2-mediated macrophage recruitment and angiogenesis. Cancer Res. 2013;73:6080-6093.

55. Melgar-Lesmes P, Edelman ER. Monocyte-endothelial cell interactions in the regulation of vascular sprouting and liver regeneration in mouse. J Hepatol. 2015;63:917-925.

56. Ehling J, Bartneck M, Wei X, Gremse F, Fech V, Möckel D, Baeck C, Hittatiya K, Eulberg D, Luedde T, Kiessling F, Trautwein C, Lammers T, Tacke F. CCL2-dependent infiltrating macrophages promote angiogenesis in progressive liver fibrosis. Gut. 2014;63:1960-1971.

57. Rowe GC, Raghuram S, Jang C, Nagy JA, Patten IS, Goyal A, Chan MC, Liu LX, Jiang A, Spokes KC, Beeler D, Dvorak H, Aird WC, Arany Z. PGC- $1 \alpha$ induces SPP1 to activate macrophages and orchestrate functional angiogenesis in skeletal muscle. Circ Res. 2014;115:504517.

58. Arderiu G, Espinosa S, Peña E, Aledo R, Badimon L. Monocyte-secreted Wnt5a interacts with FZD5 in microvascular endothelial cells and induces angiogenesis through tissue factor signaling. J Mol Cell Biol. 2014;6:380393.

59. Stefater JA 3rd, Lewkowich I, Rao S, Mariggi G, Carpenter AC, Burr AR, Fan J, Ajima R, Molkentin JD, Williams BO, Wills-Karp M, Pollard JW, Yamaguchi T, Ferrara N, Gerhardt H, Lang RA. Regulation of angiogenesis by a non-canonical Wnt-Flt1 pathway in myeloid cells. Nature. 2011;474:511-515.

60. Stefater JA 3rd, Rao S, Bezold K, Aplin AC, Nicosia RF, Pollard JW, Ferrara N, Lang RA. Macrophage WntCalcineurin-Flt1 signaling regulates mouse wound angiogenesis and repair. Blood. 2013;121:2574-2578.

61. Kikuchi R, Nakamura K, MacLauchlan S, Ngo DT, Shimizu I, Fuster JJ, Katanasaka Y, Yoshida S, Qiu Y, Yamaguchi TP, Matsushita T, Murohara T, Gokce N, Bates DO, Hamburg NM, Walsh K. An antiangiogenic isoform of VEGF-A contributes to impaired vascularization in peripheral artery disease. Nat Med. 2014;20:1464-1471.

62. Kataru RP, Jung K, Jang C, Yang H, Schwendener RA, Baik JE, Han SH, Alitalo K, Koh GY. Critical role of $\mathrm{CD} 11 \mathrm{~b}+$ macrophages and VEGF in inflammatory lymphangiogenesis, antigen clearance, and inflammation resolution. Blood. 2009;113:5650-5659.

63. Kim KE, Koh YJ, Jeon BH, Jang C, Han J, Kataru RP, Schwendener RA, Kim JM, Koh GY. Role of CD11b+ macrophages in intraperitoneal lipopolysaccharide-induced aberrant lymphangiogenesis and lymphatic function in the diaphragm. Am J Pathol. 2009;175:1733-1745.

64. Baluk P, Hogmalm A, Bry M, Alitalo K, Bry K, McDonald DM. Transgenic overexpression of interleukin-1 $\beta$ induces persistent lymphangiogenesis but not angiogenesis in mouse airways. Am J Pathol. 2013;182:1434-1447. 
65. Ji H, Cao R, Yang Y, Zhang Y, Iwamoto H, Lim S, Nakamura M, Andersson P, Wang J, Sun Y, Dissing S, He X, Yang X, Cao Y. TNFR1 mediates TNF- $\alpha$-induced tumour lymphangiogenesis and metastasis by modulating VEGF-C-VEGFR3 signalling. Nat Commun. 2014;5:4944.

66. Oliver G, Detmar M. The rediscovery of the lymphatic system: old and new insights into the development and biological function of the lymphatic vasculature. Genes Dev. 2002;16:773-783.

67. Karkkainen MJ, Haiko P, Sainio K, Partanen J, Taipale J, Petrova TV, Jeltsch M, Jackson DG, Talikka M, Rauvala H, Betsholtz C, Alitalo K. Vascular endothelial growth factor $\mathrm{C}$ is required for sprouting of the first lymphatic vessels from embryonic veins. Nat Immunol. 2004 ;5:74-80.

68. Zhang L, Zhou F, Han W, Shen B, Luo J, Shibuya M, He Y. VEGFR-3 ligand-binding and kinase activity are required for lymphangiogenesis but not for angiogenesis. Cell Res. 2010;20:1319-1331.

69. Buttler K, Becker J, Pukrop T, Wilting J. Maldevelopment of dermal lymphatics in Wnt5a-knockout-mice. Dev Biol. 2013;381:365-376.

70. Cani PD, Amar J, Iglesias MA, Poggi M, Knauf C, Bastelica D, Neyrinck AM, Fava F, Tuohy KM, Chabo C, Waget A, Delmée E, Cousin B, Sulpice T, Chamontin B, Ferrières J, Tanti JF, Gibson GR, Casteilla L, Delzenne NM, Alessi MC, Burcelin R. Metabolic endotoxemia initiates obesity and insulin resistance. Diabetes. 2007;56:1761-1772.

71. Kemp DM. Does chronic low-grade endotoxemia define susceptibility of obese humans to insulin resistance via dietary effects on gut microbiota? Adipocyte. 2013;2:188190.

72. Tynan GA, Hearnden CH, Oleszycka E, Lyons CL, Coutts G, O’Connell J, Corrigan MA, Lynch L, Campbell M, Callanan JJ, Mok KH, Geoghegan J, O'Farrelly C, Allan SM, Roche HM, O'Shea DB, Lavelle EC. Endogenous oils derived from human adipocytes are potent adjuvants that promote IL- $1 \alpha$-dependent inflammation. Diabetes. 2014;63:2037-2050.

73. Shi H, Kokoeva MV, Inouye K, Tzameli I, Yin H, Flier JS. TLR4 links innate immunity and fatty acid-induced insulin resistance. J Clin Invest. 2006;116:3015-3025.

74. Malgor R, Bhatt PM, Connolly BA, Jacoby DL, Feldmann KJ, Silver MJ, Nakazawa M, McCall KD, Goetz DJ. Wnt5a, TLR2 and TLR4 are elevated in advanced human atherosclerotic lesions. Inflamm Res. 2014;63:277-285.

75. Woldt E, Terrand J, Mlih M, Matz RL, Bruban V, Coudane F, Foppolo S, El Asmar Z, Chollet ME, Ninio E, Bednarczyk A, Thiersé D, Schaeffer C, Van Dorsselaer A, Boudier C, Wahli W, Chambon P, Metzger D, Herz $\mathrm{J}$, Boucher P. The nuclear hormone receptor PPAR $\gamma$ counteracts vascular calcification by inhibiting Wnt5a signalling in vascular smooth muscle cells. Nat Commun. 2012;3:1077.
76. Yang L, Chu Y, Wang Y, Zhao X, Xu W, Zhang P, Liu X, Dong S, He W, Gao C. siRNA-mediated silencing of Wnt5a regulates inflammatory responses in atherosclerosis through the MAPK/NF- $\kappa B$ pathways. Int J Mol Med. 2014;34:11471152.

77. Liang H, Chen Q, Coles AH, Anderson SJ, Pihan G, Bradley A, Gerstein R, Jurecic R, Jones SN. Wnt5a inhibits $\mathrm{B}$ cell proliferation and functions as a tumor suppressor in hematopoietic tissue. Cancer Cell. 2003;4:349-360.

78. Ying J, Li H, Chen YW, Srivastava G, Gao Z, Tao Q. WNT5A is epigenetically silenced in hematologic malignancies and inhibits leukemia cell growth as a tumor suppressor. Blood. 2007;110:4130-4132.

79. Bitler BG, Nicodemus JP, Li H, Cai Q, Wu H, Hua X, Li T, Birrer MJ, Godwin AK, Cairns P, Zhang R. Wnt5a suppresses epithelial ovarian cancer by promoting cellular senescence. Cancer Res. 2011;71:6184-6194.

80. Kremenevskaja N, von Wasielewski R, Rao AS, Schöfl C, Andersson T, Brabant G. Wnt-5a has tumor suppressor activity in thyroid carcinoma. Oncogene. 2005;24:21442154.

81. Weeraratna AT, Jiang Y, Hostetter G, Rosenblatt K, Duray $\mathrm{P}$, Bittner M, Trent JM. Wnt5a signaling directly affects cell motility and invasion of metastatic melanoma. Cancer Cell. 2002;1:279-288.

82. Dissanayake SK, Wade M, Johnson CE, O'Connell MP, Leotlela PD, French AD, Shah KV, Hewitt KJ, Rosenthal DT, Indig FE, Jiang Y, Nickoloff BJ, Taub DD, Trent JM, Moon RT, Bittner M, Weeraratna AT. The Wnt5A/protein kinase $\mathrm{C}$ pathway mediates motility in melanoma cells via the inhibition of metastasis suppressors and initiation of an epithelial to mesenchymal transition. J Biol Chem. 2007;282:17259-17271.

83. Ripka S, König A, Buchholz M, Wagner M, Sipos B, Klöppel G, Downward J, Gress T, Michl P. WNT5A--target of CUTL1 and potent modulator of tumor cell migration and invasion in pancreatic cancer. Carcinogenesis. 2007;28:1178-1187.

84. Smith K, Bui TD, Poulsom R, Kaklamanis L, Williams $\mathrm{G}$, Harris AL. Up-regulation of macrophage wht gene expression in adenoma-carcinoma progression of human colorectal cancer. Br J Cancer. 1999;81:496-502. 